\title{
State of Research on the History of the Lubrański Academy
}

\begin{abstract}
The article tells about historiography of a famous Polish school - Collegium Lubranscianum (English Lubrański Academy), which originated in 1519 and existed until 1780. The whole text divided into few groups, showing the position of Lubranscianum in the interpretations of historians and the lack of research allowing recognition of some aspects of Lubranscianum history, such as the educational process of young people in the school, including the methods and handbooks, or, in general, the history of the school in the seventieth and eighteenth century. It is stressed that only few works bring new knowledge into out problem and most of the historiography is based on previously published works.
\end{abstract}

Keywords: Lubrański Academy, Poznań, history of education

While discussing such an important issue as the state of research on the history of the Lubrański Academy, we should begin with "monographic", so to speak, studies, i.e. works focusing primarily on the university which is of interest to us. However, quite surprisingly, only a few such studies have been conducted. On the other hand, the historiographical scarceness in this respect allows us to look more closely at the achievements which have been made.

The first attempt at a comprehensive presentation of the history of the Lubrański Academy was undertaken by Józef Łukaszewicz, who published the effects of his work in two places: a historical and statistical study of the city of Poznan ${ }^{1}$ and a monograph devoted to the history of education in the Kingdom of Poland and the Grand Duchy of

1 ŁUKASZEWICZ, J., Obraz historyczno-statystyczny miasta Poznania $w$ dawniejszych czasach, vol. 1-2, Poznań 1838. 
Lithuania $^{2}$. As both works on the Lubrański Academy are compatible, and in fragments, even identical, we can discuss them together ${ }^{3}$.

According to Eukaszewicz the reason for the founding of the school was the social demand for higher education in Poznań, which would enable young people to take up various professions. The author informs the readers about the school's equipment with Stawiszyn goods and the approval of the foundation by King Zygmunt I in 1520. He then states, and this is particularly interesting, that "Lubrański, by establishing his school, made it a colony of the Krakow Academy, which was obliged to provide Lubranski's college with a rector and professors ${ }^{4}$." Łukaszewicz said, however, that he took such a stance following Mikołaj Zalaszowski, because personally he could not find appropriate source materials. He rightly pointed out, however, that "[...] there are facts in the history of the school, proving that the Krakow Academy failed to provide it, especially in the 16th century, with teachers" . Apart from the issue of the autonomy of Lubranscianum, the author also focuses on the education of the youth.

Józef Łukaszewicz emphasized the contributions of Tomasz Bederman and Grzegorz from Szamotuły, its first rectors and bishop Jan Latalski, a patron who also brought Krzysztof Hegendorfer from Leipzig. He pointed out that at that time, Józef Struś, Klemens Janicki and "other outstanding people" were studying at the school. In terms of the curriculum, Łukaszewicz quotes one of the elegies of Klemens Janicki, who wrote: Gymnasium petii, nuper Lubrancus amoeni $\mid$ Ad Vartae vitreas quod fabricarat aquas ${ }^{7}$. From the subsequent part of the quoted work, we learn that, at least from Janicki's point of view, in Lubranscianum the focus was on ancient literature, the representatives of which were the immortal Virgil and the divine Ovid ${ }^{8}$. This is the only information about the educational profile in the early period of the Lubrański Academy presented by Józef Łukaszewicz. He associated the decline of the school's position with the fact that Jan Latalski took over the bishopric in Kraków, adding, however, that Grzegorz of Szamotuły also significantly contributed to the decline causing the removal of Krzysztof Hegendorfer from Poznań. Along with this fact, the Rector was forced to remove the teaching of classical literature, introducing "the logics of Piotr the Spaniard, the works of Głogowczyk and others" instead".

The further history of the university was also described quite briefly. Chronologically, the next discussed issue (after the departure of Bishop Jan Latalski) was the appearance

${ }^{2}$ ŁUKASZEWICZ, J., Historya szkół w Koronie i $w$ Wielkiem Księstwie Litewskiem od najdawniejszych czasów aż do roku 1794, vol. 3, Poznań 1851.

3 The citation according to: ŁUKASZEWICZ, J., Historya szkót will be used.

${ }^{4}$ Ibidem, p. 483 and next.

5 Ibidem, footnote 1, p. 484.

6 Ibidem, p. 485.

7 Ibidem, p. 484.

8 Ibidem, p. 484.

9 Ibidem, footnote 1, p. 485. 
of Benedykt Herbest and Grzegorz Samborczyk in Poznań, who were invited by Bishop Andrzej Czarnkowski. During their term Lubranscianum became one of the best schools in Poland and even in Germany ${ }^{10}$. However, the establishment of a Jesuit school in Poznań, as the author emphasizes, and what is more, the special care of Bishop Adam Konarski, combined with the neglect of the university located in Ostrów, ultimately led to another crisis of the latter. Having described the physical state of the university on the basis of the revision of 1571, Łukaszewicz moved on to the problems related to the renewal of the school, with the efforts of the Poznan chapter and the generous donation of Jan Rozdrażewski ${ }^{11}$.

In contrast to the earlier period, the resumption of activity is discussed very precisely by Józef Łukaszewicz. To begin with, he presents the new statute of the university, which, as he emphasizes, was rewritten by Jan Rozdrażewski ${ }^{12}$. However, he fails to provide information on the source ${ }^{13}$. The inclusion of the entire document in his publication was a great advantage, as it enabled access to its content. In the further part of the work, the author discussed the organizational structure of the school, especially regarding teachers, the school library, enriched with the donation of Mikołaj Zalaszowski, as well as the printing house, he also mentioned the mathematical tools in the school's possession. In addition, he also mentioned individual rectors of Lubranscianum, who had been running the college for three centuries ${ }^{14}$. The paragraph devoted to the academic printing press is particularly noteworthy, because the author, using a certain Poznań calendar, cites numerous examples of publications, to some extent portraying its scientific profile ${ }^{15}$. Lukaszewicz depicted educational issues elsewhere in the first volume of his work ${ }^{16}$. However, he limited his analysis to the statute of 1619 and its further amendments, such as the introduction of the French language instead of $\mathrm{Greek}^{17}$.

Summing up the remarks concerning the work of Józef Łukaszewicz, it must be stressed that his extraordinary interest in the subject of the former Poznan university is of great significance. Despite numerous generalisations, the author drew attention to several important issues, however, discussing them here would be pointless.

Another work devoted entirely to the Lubrański Academy was developed after a long break. In 1921, a doctoral dissertation by priest Karol Mazurkiewicz was published, how-

${ }^{10}$ Ibidem, p. 486.

${ }^{11}$ Ibidem, p. 487 the author discusses the issue of remuneration later in the work, cf. p. 498 and next.

12 Ibidem, p. 487.

${ }^{13}$ Research carried out by: NOWACKI, J., “Akademia Lubrańskiego”, Kronika Miasta Poznania 1999, no. 2, p. 167 indicates that the preparation of this statute was taken up by the Poznań Chapter, which on July 1 , 1619 , chose a commission consisting of seven of its members for this purpose.

14 ŁUKASZEWICZ, J., Historya szkót, p. 506.

15 Ibidem, p. 507.

${ }^{16}$ ŁUKASZEWICZ, J., Historya szkół w Koronie i w Wielkiem Księstwie Litewskiem od najdawniejszych czasów aż do roku 1794, vol. 1, Poznań 1849, p. 212 and next.

${ }^{17}$ Ibidem, p. 215. 
ever, it concerned only the beginnings of the Poznan Academy ${ }^{18}$. In any case, this does not diminish its cognitive value. On the contrary. The limitation of the research to a certain period contributed to a more thorough examination of the issue. Thanks to this, it has been permanently inscribed in the history of Polish historiography.

An undoubted advantage of the work, in contrast to the one discussed above, is the accurate presentation of the source material, which makes it possible to verify the author's findings. It was divided into several transparent parts, the first of which discussed the state of education in Poznan at the beginning of the $16^{\text {th }}$ century, the next two parts presented Krzysztof Hegendorfer and Grzegorz from Szamotuły, while the following chapter was devoted to the conflict between these two. In the first part, Fr. Mazurkiewicz briefly presented the image of Poznan at that time, mentioning the schools functioning in the area: a primary school at the parish church and a higher school - Tumska, operating in accordance with the "traditional" canons of teaching ${ }^{19}$. The author then moves on to discuss the motives of the foundation of bishop Jan Lubrański, which he sees as the desire to have a modern school for the entire Wielkopolska region with an "academic system" for raising an educated and godly clergy capable of opposing religious opponents. At this point, a question arises: did the humanist bishop, who corresponded with Aldo Manucius - one of the most renown printers of the Renaissance - really care only for the education of a group of faithful priests? Of course, this question will remain unanswered, as we are unable to penetrate the founder's intentions.

Mazurkiewicz took the same position as Józef Łukaszewicz regarding the dependence of Lubranscianum from the Krakow Academy. However, he presented a broader argumentation, and justified the doubts of the former in the matter of bringing, for example, Hegendorfer from Leipzig, with the argument that the Krakow Academy did not have humanist professors at that time, so it could not offer them to the university in Poznań. Fr. Mazurkiewicz also stated that in most cases it was a rule that professors lecturing at the Poznań college came from the Krakow university, while all the rectors received their degrees in $\mathrm{Krakow}^{20}$.

On the following pages, the author discussed the formal issues related to the organization of the school, both internal and ensuring its economic functioning. A separate fragment was devoted to the presentation of the theological and humanities faculties, along with the subjects taught and the characteristics of some lecturers. The two most important persons associated with the discussed topic became the object of special interest of the author, i.e. Krzysztof Hegendorfer and Grzegorz from Szamotuły. Their lives were presented in detail, especially in relation to the period of teaching at the Poznan school. The history of the dispute which emerged between them was described in a very precise way, both from the theological and philosophical perspective, legal and finally also personal. The au-

18 MAZURKIEWICZ, K., Początki Akademji Lubrańskiego w Poznaniu (1519 - 1535). Przyczynek do dziejów rozwoju nauk humanistycznych w Polsce, Poznań 1921.

19 Ibidem, p. 3 and next.

${ }^{20}$ Ibidem, p. 7. 
thor finishes his reflections on the early history of Lubranscianum with this dispute, writing only a few sentences about its further fate, finishing with the liquidation of the academy in 1780. To conclude, it is clear that the work of priest Karol Mazurkiewicz, despite the passage of time, deserves special attention, because, given the scarcity of source materials, the author made a very thorough analysis of the problem.

The beginnings of the Lubrański Academy in Poznań do not exhaust Mazurkiewicz's work related to the Poznań Academy. His work devoted to Benedict Herbest, a great scholar of the $16^{\text {th }}$ century, whom Lubranscianum had the honour to have among its lecturers, is also worth noting ${ }^{21}$. Despite his concentration on the person of Herbest, Mazurkiewicz also depicted the general history of the Academy in the period preceding the arrival of the scholar. He paid particular attention to matters related to the theological faculty, presenting the profiles of selected professors, such as Stefan Mikan, doctor of medicine and lecturer of dialectics and rhetoric in Lubranscianum ${ }^{22}$ or the organizational matters of the faculty, the number of lecturers, their status within church structures, as well as remuneration ${ }^{23}$. Subsequent pages discuss the special situation in the college, which ultimately led to its periodic decline. This event, as well as the process of renewal of the Poznan university, was discussed separately ${ }^{24}$. The author then went on to discuss the activities of Benedykt Herbest at the Collegium Lubranscianum. This study should be considered as particularly interesting, because it attempts to show the youth education system, i.e. school organization, teaching methods and textbooks ${ }^{25}$. Finally, it is worth noting that author was also interested in the plagues prevailing in Poznań, which of course had a great impact on the fate of the university ${ }^{26}$.

A year following the publication of the work discussed above, the author published an article, based on a paper delivered at the consecration of the Archdiocesan Archives on May 27, 1926 ${ }^{27}$. It discussed the history of the Lubrański Academy, once located in the Archives building. As we can read in the content, the basis of the new publication were two previous works devoted to the history of the Academy, as well as the unpublished studies of the Author ${ }^{28}$.

The article, though not very extensive, discusses the entire history of Lubranscianum. The origins of the school and its internal organization were briefly presented, including a description of professors' positions and the subject matter they dealt with. Mazurkiewicz

${ }^{21}$ MAZURKIEWICZ, K., Benedykt Herbest: pedagog-organizator szkoły polskiej XVI wieku, kaznodzieja-misjonarz doby reformacji, Poznań 1925.

${ }^{22}$ Ibidem, p. 165 and next. Other professors of this faculty were discussed on p. 169-171.

${ }^{23}$ Ibidem, p. 168.

${ }^{24}$ Ibidem, p. 172-174.

25 Ibidem, p. 230-245.

${ }^{26}$ Ibidem, p. 252-254.

${ }^{27}$ MAZURKIEWICZ, K., “Akademia Lubrańskiego w Poznaniu”, Wiadomości dla Duchowieństwa, 1926, coll. 7-9.

${ }^{28}$ Ibidem, p. 11. 
compared the lower college, i.e. the humanities department with the higher college with the right to grant the first academic degree, and also with the faculty of liberalium artium in Krakow $^{29}$. The theological department, on the other hand, in the absence of a seminary at the beginning of the $16^{\text {th }}$ century, was to educate candidates for priesthood ${ }^{30}$. The study briefly discusses the history of the Lubrański Academy in the following years of its existence, including the history of the conflict between Krzysztof Hegendorfer and Grzegorz Szamotulczyk. This time, however, the author did not focus only on the said dispute, but tried to characterize other, more distinguished lecturers. The collapse of the university after the departure of Benedict and Jan Herbest to the Jesuit order, as well as the issue of the transfer of the theological faculty in 1581 to the order were presented quite thoroughly ${ }^{31}$. Karol Mazurkiewicz devoted a lot of attention to the renewal of the Academy, especially in terms of remuneration, as well as its organization, elaborating on these issues in various parts of the study. One can thus find information on individual university benefactors, the partially or entirely owned farms, monastery schools, printing houses, libraries, as well as the equipment and the condition of academic rooms (based on Minocki's report from 1774 for the National Education Committee). The statutes of the $17^{\text {th }}$ century and a new law of 1719 were also discussed.

Despite the small volume of work, which is understandable due to the purpose of its creation, it is important to emphasize its significance. This is the second comprehensive approach to the history of the Lubrański Academy, developed by an undisputed expert on the subject. It is a pity that having access to a broad source base, he did not decide to make a more detailed monograph.

Another very important contribution to the history of the Collegium Lubranscianum is the work of priest Józef Nowacki, which is a monograph of the history of the Archdiocese of Poznań, with a separate fragment devoted to the school that is of interest to us ${ }^{32}$. In the introduction to the study, Józef Nowacki briefly discussed the source materials related to the history of the Academy, stating that a majority of them, i.e. documents, books and files containing professors' lists and information about the school's activities were taken over in 1780 by the National Education Commission and, as most probably lost or destroyed ${ }^{33}$. Therefore, only the Archive of the Metropolitan Chapter remained the source basis ${ }^{34}$. The work in question has been divided, in chronological order, into two equal parts. The first one covers the 16th century, the second one the years 1609-1780.

29 Ibidem, p. 13.

30 Ibidem, p. 12.

31 Ibidem, p. 18.

32 NOWACKI, J., Dzieje archidiecezji poznańskiej, vol. 2: Archidiecezja poznańska w granicach historycznych i jej ustrój, Poznań 1964, p. 678-702. In this work the quotation according to the following reprint will be used: NOWACKI, J., “Akademia Lubrańskiego”, Kronika Miasta Poznania, 1999, no. 2, p. 152-180.

33 NOWACKI, J., “Akademia Lubrańskiego”, p. 153.

${ }^{34}$ The author does not discuss works published by people associated with the Lubrański Academy, where you can find some information about it. 
It must be emphasized that the work of Józef Nowacki is distinguished by a very solid source basis. In principle, every statement is supported by appropriate materials. The author presents the events related to the founding of the school, recalling the relevant documents ${ }^{35}$, discussing its legal position within the Poznan Church and emphasizing its independence in the $16^{\text {th }}$ century from the University of Krakow ${ }^{36}$. Economic issues related directly to the existence of the school were also included in the work. According to Nowacki, the aim of the school was a better preparation of future clergy - hence the study of theology, preceded by humanistic studies ${ }^{37}$. The next part discusses the most important lecturers of both theological and humanistic studies, as well as distinguished students ${ }^{38}$. A lot of space is also devoted to the periods of partial decline of the Academy, as well as to the efforts of the Poznan chapter to renew it ${ }^{39}$.

The second part of the chapter devoted to the Lubrański Academy begins with the statement that the chapter undertook the task of renewing the school due to the needs of the cathedral church $^{40}$, discussing the undertaken efforts. The stages of the renewal process of the Lubrański Academy, starting from the testament records of Jan Rozdrażewski ${ }^{41}$, including its links with the history of the Jesuit College, are quite carefully presented. The new organization of the Academy has been described in detail, both on the basis of Rozdrażewski's will (although the content of the will is unknown), as well as later decisions, e.g. the entry in the episcopal files of 17 May 1619 entitled Ordinatio Academicorum Collegi Lubransciani ad ecclesiam cathedral Posnaniensem siti ${ }^{42}$ or the final statute approved by the chapter on July 1, 161943. Józef Nowacki characterized the renewed Academy by taking into account several aspects, namely the economic aspect, including the Academy and professors' remuneration, as well as its physical condition ${ }^{44}$; the legal aspect, defining its position in the structures of the bishopric and the degree of dependence on the University of Krakow ${ }^{45}$. He also gives information about the library, the printing

\footnotetext{
35 Ibidem, p. 153.

36 Ibidem, p. 154.

37 Ibidem, p. 155.

${ }^{38}$ Ibidem, p. 155-163.

39 Ibidem, p. 160-164.

${ }^{40}$ Ibidem, p. 164. In this case, however, the grounds for this claim were not given.

${ }^{41}$ Ibidem, p. 164-168.

42 Ibidem, p. 166.

43 Ibidem, p. 167.

44 Ibidem, p. 165-175.

${ }^{45}$ Ibidem, p. 168 and next; p. 172-174. At this point, it is worth noting that Józef Nowacki only emphasized the partial dependence on the authorities of the Kraków university and the predominant significance of the
} chapter. 
house, the students and very briefly the curriculum. In the end he discusses the decision to close the Lubrański Academy undertaken by the National Education Commission ${ }^{46}$.

The work of Józef Nowacki, thanks to its objectivity, credibility and verifiability constitutes a very good basis for further studies on the history of Collegium Lubranscianum. It should be noted that the author was mainly interested in economic and legal issues related to the school's functioning, which should not be surprising in the context of the entire monograph of the archdiocese's history.

The next historiographical step towards completing the history of the Academy was the voice of a historian of education. On the pages of the "Chronicle of the City of Poznan'" in 1999, in a collective work devoted to Bishop Jan Lubrański and the school he created, Dorota Żołądź-Strzelczyk presented her position on this issue ${ }^{47}$. From the very beginning, the author focuses on the establishment of the school founded by the Bishop Lubrański within the context of the so-called renaissance schools established in Europe at that time, underlining the innovation of this undertaking and, what is important, a new quality in the profile of students' education ${ }^{48}$. The transformations of this profile were also discussed, as well as the individual stages of the Academy's history, first in outline ${ }^{49}$ and then in detail $^{50}$.

After presenting the genesis of the school, the author expressed her position concerning the dependence on the Krakow Academy, recognizing the independence of the Poznań university in the 16th century. She also outlined such issues as the legal status, internal organization, as well as the curriculum, with an emphasis on antiquity ${ }^{51}$. A separate fragment was devoted to the conflict between Krzysztof Hegendorfer and Grzegorz from Szamotuły, taking into account the consequences of this event for the further fate of the school ${ }^{52}$, which were also briefly described. In the subsequent part of the article, issues such as the renewal of the school at the beginning of the 17 th century, the dependence on the University of Kraków and the liquidation of Lubranscianum by the decision of the National Education Commission were discussed ${ }^{53}$. The author did not forget about the students of the college, devoting a lot of space to discuss a few well-known silhouettes, as well as their social origin ${ }^{54}$.

\footnotetext{
${ }^{46}$ Ibidem, p. 174 and next.

${ }^{47}$ This publication will be discussed later in the work.

48 ŻOŁĄDŹ-STRZELCZYK, D., “Academia Lubransciana (1519-1780). Dzieje szkoły od powstania do czasów Komisji Edukacji Narodowej”, Kronika Miasta Poznania, 1999, no. 2, p. 141.

49 Ibidem, p. 142 and next.

${ }^{50}$ Ibidem, p. 144-150.

51 Ibidem, p. 144-146.

52 Ibidem, p. 146.

${ }^{53}$ Ibidem, p. 148 and next.

${ }^{54}$ Ibidem, p. 150.
} 
The presented work is the last attempt of a comprehensive approach to the history of the Lubrański Academy, and although it has a sketchy character, it introduces new elements that allow us to learn more about the topic. The history of Lubranscianum was also the theme of several minor works, which focused only on some of the issues from its history. Due to the fact that they do not bring any new information with respect to historiography, only their general characteristics will be described.

Chronologically speaking, we should begin with a nineteenth-century publication dealing with the subject of the Poznań Academy. In 1836, as part of the "Theological Archive", the Statutes of the Lubrański College in Poznań from 1619 were published, including a brief commentary containing general information about the source ${ }^{55}$. A more important publication from the point of view of historiography was the text of Stanisław Kossowski published in 1905 concerning the person of Krzysztof Hegendorfer at the Lubrański Academy ${ }^{56}$. In addition to the characteristics of the Leipzig Master, it presented a lot of interesting information related to the general history of the school and its students. Particularly, the early years of the university, along with the figures of certain professors like Antoninus Gallus and Antoninus Niger.

Subsequent studies have made a less significant contribution. The "Chronicle of the City of Poznań" in 1930 and 1932 presents two opinions in the form of a review or rather a brief description, but referring only to fragments of works related to the Poznan school. The first concerned the work of Bronisław Nadolski entitled "On the teaching of Greek in Poland in the 16th century"57, the second, slightly more extensive, discussed the book of Henryk Barycz, which deals with the issue of universities in Poland in the 16th century ${ }^{58}$. The article published in 1947 in Przeglad Wielkopolski is a great disappointment ${ }^{59}$. The author, who in the title suggests the desire to describe the role and significance of the Lubrański and Jesuit College for Wielkopolska, provides only a few facts concerning the history of these schools. Two articles published in the "Catholic Guide" in the 1960s seem more interesting. The first discussed Poznan's efforts to create a university, which began in 1519 , and presented the history of the school that was created at the time ${ }^{60}$. The second was concerned with the beginnings of the Poznań seminary, which the author related to the

55 Statuta kollegium Lubrańskiego w Poznaniu, Archiwum Teologiczne 1836 Y.I, coll.2, p. 210.

${ }^{56}$ KOSSOWSKI, S., Krzysztof Hegendorfin $w$ akademii Lubrańskiego $w$ Poznaniu w latach 15301535. Monografia z dziejów odrodzenia i reformacji w Polsce, vol. 1: Studya do dziejów renesansu i reformacji $w$ Polsce, Lviv 1905. The Polish edition is similar to the previous study: Idem, Christophorus Hegendorphinus in der bischoflinden Akademie zu Posen (1530-1535), Lemberg 1903.

57 WOJTKOWSKI, A., “Język grecki w Poznaniu”, Kronika Miasta Poznania, 1930, no. 2, p. 185-187.

58 WOJTKOWSKI, A., “Czy Akademia Lubrańskiego była uniwersytetem?”, Kronika Miasta Poznania, 1932, no. 1, p. 118 and next.

${ }^{59}$ GOŁĘBIOWSKI, "Rola i znaczenie Kolegium Lubrańskiego i Kolegium Jezuickiego w XVI, XVII i XVIII wieku dla Wielkopolski”, Przegląd Wielkopolski, 1947, no. 1-3.

${ }^{60}$ WIKTOR, K., “W cieniu Akademii Lubrańskiego”, Przewodnik Katolicki, 1961, 51, no. 41, p. 651. 
College of Lubrański ${ }^{61}$. He argued that the study of law and theology did not dominate at the Poznań Academy, but was equal with other disciplines ${ }^{62}$. He also defended the view on the legal independence of the university in relation to the University of Krakow, arguing that the close relationship with the Krakow university did not make the academy a university colony ${ }^{63}$. The article then briefly describes the history of Lubranscianum, the foundation of Jan Rozdrażewski and subsequent assignments, as well as the library and academic printing house. The next article, devoted entirely to the history of the Lubrański Academy, was written in 1998 and presented a popular approach, depicting the founder of the school, the initial education goals which were identified with the preparation of candidates for the clergy and basic information about the history of the Academy ${ }^{64}$.

The publication from 1999, as part of the "Chronicle of the City of Poznań", requires a separate discussion. The intention was to "come face to face with two Poznań myths - the myth of the highly-valued bishop Jan Lubrański and the glorious tradition of the school he founded. ${ }^{65 "}$ The published volume of the Chronicle entitled "Jan Lubrański and his work" is the result of the conference "The World of Bishop Jan Lubrański" held in February 1999 on the occasion of the anniversary of the ingress of Jan Lubrański to the Poznań Chair. The first part of the publication was devoted to the bishop, including his library ${ }^{66}$, while the second presents articles related to the bishop's Academy. There are two articles about the history of the Academy by Dorota Żołądź-Strzelczyk and Józef Nowacki, which have already been discussed above. Renata Linette presented the history of the building in which the Academy was located ${ }^{67}$, Jan Sójka discussed the fate of the printing house in the Academy, taking into account its publishing profile ${ }^{68}$. In addition, there are also two interesting translations from Latin, made by Anna Pawlaczyk. This enabled access to the Principles of Studying by Krzysztof Hegendorfer ${ }^{69}$ and the Statutes of the Lubrański Academy from $1619^{70}$. These were supplemented with two very useful

${ }^{61}$ WIKTOR, K., “A więc jeszcze przed Soborem Trydenckim”, Przewodnik Katolicki, 1963, 53, p. 235 and next.

62 Ibidem, p. 235.

63 Ibidem, p. 236.

${ }^{64}$ REZLER, M., “Collegium Lubranscianum”, Głos Wielkopolski, 1998, 1st ed., no. 231, p. 14.

65 “Od redakcji”, Kronika Miasta Poznania, 1999, no. 2, p. 5.

${ }^{66}$ MARCINIAK, R., "Biblioteka biskupa Jana Lubrańskiego”, Kronika Miasta Poznania, 1999, no. 2, p. 111-126.

${ }^{67}$ LINETTE, R., “Z dziejów budynku dawnej Akademii Lubrańskiego”, Kronika Miasta Poznania, 1999 , no. 2, p. 181-212.

68 SÓJKA, J., "Drukarnia Akademicka w Poznaniu 1689-1780”, Kronika Miasta Poznania, 1999, no. 2, p. $236-251$.

${ }^{69}$ PAWLACZYK, A., "Krzysztofa Hegendorfa Racja Studiowania”, Kronika Miasta Poznania, 1999, no 2, p. 213-227.

70 PAWLACZYK, A., "Statuta Akademii Lubrańskiego z 1619 roku”, Kronika Miasta Poznania, 1999, no. 2, p. 236-251. 
materials: Wanda Karkucińska prepared a catalogue of publications of the Akademicka Printing House ${ }^{71}$, while Jacek Wiesiołowski presented materials related to the Krakow professors of Lubranscianum ${ }^{72}$.

The most recent studies include the work devoted to Benedykt Herbest and two works generally dedicated to the Lubianski Academy. The work on the sixteenth-century rector of Lubranscianum presents basic information about his life and career in science, including a dispute with Jakub Górski and events that influenced his arrival at the school in Poznan ${ }^{73}$. Unfortunately, the author discussed his scientific and pedagogical activity in Wielkopolska only briefly, and therefore the value of the work with respect to the history of Collegium Lubranscianum is scarce. On the other hand, the "Unknown" Academy of Poznan elaborates on the subject in terms of the history of material culture. The author combined the history of the school building founded by the Bishop Lubrański with the fortifications of Ostrów Tumski and discussed the process of its formation ${ }^{74}$. The interiors of Lubranscianum were also described ${ }^{75}$. The second work by the same author was written, as he himself admits, "in addition to the construction works carried out in the Academy building" "76 , the history of the Lubrański Academy is also a major part of the study, also in the chapter devoted to the history of the school. The book discusses the figure of Jan Lubrański, archaeological discoveries, the history of the Academy building, the history of the Academy and information about the Archdiocesan Museum currently located in the building. As for the part devoted to the history of the Academy, it does not provide any new information about the history of the college. It is worth taking a closer look at the study on the building itself, and the archaeological research of the history of art also sheds some light on the history of the school itself. It is obvious that by getting to know the exact layout of the school's interior we get closer to the understanding of the everyday life of its employees and students. The author made a detailed description of individual rooms of the building, providing his own suggestions for their destination ${ }^{77}$. It should be noted that the book also presents patterns, which were most probably used during the implementation of the college's construction project ${ }^{78}$.

${ }^{71}$ KARKUCIŃSKA, W., "Katalog publikacji Drukarni Akademickiej w Poznaniu”, Kronika Miasta Poznania, 1999, no. 2, p. 252-298.

72 WIESIOŁOWSKI, J., "Krakowscy profesorowie Akademii Lubrańskiego. Materiały”, Kronika Miasta Poznania, 1999, no. 2, p. 299-324.

73 PIĘTKA, R., "Benedykt Herbest - rektor Akademii Lubrańskiego [w Poznaniu]", Kronika Miasta Poznania, 2006, no. 4, p. 62-67.

74 SKURATOWICZ, J., “Nieznana” Akademia Lubrańskiego w Poznaniu, [in:] Tu się Polska zaczęła...: wydawnictwo pokonferencyjne, ed. H. KÓCKA-KRENZ, Poznań 2007.

75 Ibidem, p. 52.

${ }^{76}$ SKURATOWICZ, J., Akademia Lubrańskiego : pomnik wielkopolskiej kultury i nauki, Poznań 2007, p. 5 .

77 Ibidem, p. 38 and next.

${ }^{78}$ Ibidem, p. 37 and next; p. 53. 
Two works related to the history of the colonies of the University of Krakow require a separate discussion. Chronologically, the first one is, to a certain extent, the reason of further research on the issue of ideological and organizational foundations of academic colonies, created in Poland since $1588^{79}$. At the beginning, the author of the extended and supplemented habilitation lecture thoroughly discussed the subject literature, including the work on individual school-colonies, stating, however, that it was an incomplete, indicative compilation. The article, which in principle is merely a sketch, presents a number of important issues related to the functioning of academic colonies. One should mention, for example, the analysis of the term "colony", the functioning of the teaching staff, the specificity of the curriculum or the operation of the administrative and supervisory apparatus. It is worth noting that great attention was paid to the teaching of Polish, Polish history and law $^{80}$, and enabling lower levels of society access to secondary and higher education ${ }^{81}$. These studies were continued by Wojciech Grzelecki, the result of which was a monograph devoted to the history of the colony of the Jagiellonian University, with particular emphasis on the issues of education and upbringing ${ }^{82}$. A lot of space was devoted to the characteristics of the humanistic, Renaissance school ${ }^{83}$, the objectives of Renaissance education and the values of its individual elements ${ }^{84}$, as well as the skills that students could master in the academy ${ }^{85}$. A separate issue was the analysis of the term "colony" along with the presentation of various aspects of the organization of schools subordinate to the Krakow University ${ }^{86}$. In addition to the characteristics of the humanities school, the author presented the typical features of the educational and scientific profile of university colonies, juxtaposing them with the characteristics of the Jesuit schools ${ }^{87}$. The functioning of school-colonies, including their internal organization, the degree of dependence on the university, the profile of teaching was depicted in details, together with the discussion of subjects, teachers and their work, devoting a lot of space to the analysis of the textbooks used. The issues related to students, i.e. their origin, everyday life, methods of teaching, their activities, also in the literary or the theater field, have not been omitted ${ }^{88}$.

79 HAJDUKIEWICZ, L., "Podstawy ideowe i organizacyjne kolonii akademickich Uniwersytetu Krakowskiego (1588-1773/1775). Stan badań, problematyka, postulaty”, Przegląd Historyczno-Oświatowy, 1963, 6, no. 2 .

${ }^{80}$ Ibidem, p. 166.

81 Ibidem, p. 175.

${ }^{82}$ GRZELECKI, W., Szkoły - kolonie Uniwersytetu Krakowskiego 1588-1773. Problematyka ksztatcenia i wychowania, Wrocław 1986.

83 Ibidem, p. 9 and next.

${ }^{84}$ Ibidem, p. 16; p. 22-24.

85 Ibidem, p. 17.

86 Ibidem, p. 18-22.

${ }^{87}$ Ibidem, p. 24-28.

${ }^{88}$ Ibidem, passim. 
It should be noted that thanks to the comprehensive approach to the problem of university colonies and the use of materials from various "branches", the author managed to present a relatively complete picture of the history of these schools. However, one should be aware that the program implemented by teachers in some aspects could have been different from the model program proposed by Wojciech Grzelecki. Other studies that should be discussed have a less significant value for understanding the history of Lubranscianum, based mainly on earlier works, and are related to the monographs of the history of Poznań and its university traditions.

Regarding the first group, the characteristic should start with a collective work entitled Ten Centuries of Poznań, the second volume of which is devoted to various aspects of cultural history. In one of the chapters dealing with intellectual and literary life, we find some information about the Lubrański Academy, but only of a general nature ${ }^{89}$. Basic information about the history of the Academy, its curriculum or legal relationship to the University of Kraków. It is worth noting that a lot of space was devoted to the presentation of the students of the Lubrański College and their works. Another chapter is devoted to the history of the theatre in Poznań ${ }^{90}$, and it also mentions the scene of the Lubrański Academy. Unfortunately, information about the theatre is limited only to a few words. The extensive study of the history of Poznan is also noteworthy, as much attention was devoted to the history of education and intellectual culture in general ${ }^{91}$. A fragment of the first part of the monograph devoted to the Lubrański Academy discusses its foundation, organizational structure, teaching staff and briefly the teaching profile ${ }^{92}$. The dispute between Krzysztof Hegendorfer and Grzegorz from Szamotuły was also discussed, as apart from the loss of financial security it also contributed to the decline of the $\mathrm{school}^{93}$ and its further fate, underlining the importance of the Herbest brothers for the prosperity of the Academy. Then, the subsequent decline of the university, the foundation of Jan Rozdrażewski from $1609^{94}$, the renewal of Lubranscianum and several matters related to the life of students, such as their origin, benefits, prizes, scholarships were discussed ${ }^{95}$. Another fragment devoted to scientific life, medicine and printing, includes information about the lecturers and students of the Lubrański Academy, especially regarding their scientific achievements ${ }^{96}$. The second part of the work, unfortunately, does not depict the further history of the Academy, i.e. after its renewal in the early $17^{\text {th }}$ century. It mentions only the character-

89 SKORUPSKA, Z., Życie umystowe i literackie do 1793 r., [in:] Dziesięć wieków Poznania, vol. 2: Kultura umysłowa, literatura, teatr i muzyka, Poznań-Warsaw 1956.

90 GROT, Z., Teatr do 1918 r., [in:] Dziesięć wieków Poznania, vol. 2: Kultura umysłowa, literatura, teatr i muzyka, Poznań-Warsaw 1956.

${ }^{91}$ Dzieje Poznania, vol. 1, parts 1-2: Do roku 1793, ed. J. TOPOLSKI, Warsaw-Poznań 1988.

92 Ibidem, vol. 1, part. 1, p. 504-506.

93 Ibidem, vol. 1, part. 1, p. 506.

94 Ibidem, vol. 1, part. 1, p. 507.

95 Ibidem, vol. 1, part. 1, p. 508.

96 Ibidem, vol. 1, part. 1, p. 517-538. 
istics of the teaching profile based on the "Rozdrażewski foundation", auxiliary institutions, such as the library, the printing house and the collection of mathematical and physical tools ${ }^{97}$ and the academic theatre ${ }^{98}$.

A lot of attention in historiography has been devoted to the university traditions of Poznań. The beginnings of this particular interest date back to the founding of the Poznan University. In 1919, a historical sketch of the Poznań Academy was published, in which the fate of its predecessor, the Lubrański Academy, was discussed in great detail ${ }^{99}$. This work was clearly based on Łukaszewicz's publications, so there is no need for a more detailed discussion of it. It is worth noting, however, that the author focused on the structures and organization of the Academy, the relationships with the University of Krakow, educational and teaching methods, of which he presented a negative opinion ${ }^{100}$. Another work of this type appeared in print in $1924^{101}$, and was based in to a large extent on the already published book by Karol Mazurkiewicz about the beginnings of Lubranscianum and the earlier work of Łukaszewicz. The author described the general history of the school, taking into account its benefactors, the material conditions, but omitting the curriculum. On the occasion of the 50th anniversary of the Adam Mickiewicz University in Poznań, another monograph appeared, also containing an article devoted to Collegium Lubranscianum ${ }^{102}$. In principle, as in previous studies, it presents general information about the history of the school, however, what is worth noting, it also discusses the Ordinatio studiorum from $1756^{103}$. A relatively new study is the account of Zygmunt Boras from $2003^{104}$, but unfortunately the author limited himself, for unknown reasons, to presenting only the sixteenthcentury history of the Lubrański Academy. Using his own research, and not only previous studies, he showed the general history of the school in the 16th century, including the founder and the beginnings of its existence, especially the years of the liberated arts lectures by Krzysztof Hegendorfer. The author discusses the organization of the school, including a brief description of the curriculum, as well as the profiles of certain lecturers including Benedykt Herbest, at which point he concludes the part of the work devoted to the Academy.

Looking at the compilation of literature on Collegium Lubranscianum, one can notice a few characteristic problems. The most significant is the disproportion in the elaborations on the history of the Poznań university, to the detriment of its history of the 17th

\footnotetext{
${ }^{97}$ Ibidem, vol. 1, part. 2, p. 687.

98 Ibidem, vol. 1, part. 2, p. 691.

99 PNIEWSKI, W., Poznań Academy. Historical sketch, Poznań 1919.

${ }^{100}$ Ibidem, p. 8. The author claimed that the Academy taught how to write distasteful and meaningless panegyrics, conduct pointless disputes, learn Cicero by heart and stage senseless plays.

101 WRZOSEK, A., Założenie Uniwersytetu Poznańskiego i pierwsze lata jego istnienia, Poznań 1924.

102 GROT, Z., Czterysta lat walki o uniwersytet w Poznaniu, [in:] Dzieje Uniwersytetu im. Adama Mickiewicza 1919-1969, ed. Z. GROT, Poznań 1972.

${ }^{103}$ Ibidem, p. 15 and next.

104 BORAS, Z., Tradycje uniwersyteckie Poznania, Poznań 2003.
} 
and 18th centuries. The second issue is the little interest of researchers in the education of young people in this school. To some extent, this gap is filled by the studies of Józef Łukaszewicz, Karol Mazurkiewicz, and Wojciech Grzelecki or Dorota Żołądź-Strzelczyk, from a more recent perspective.

\section{Bibliography}

"Od redakcji”, Kronika Miasta Poznania 1999, No. 2: Jan Lubrański i jego dzieło.

"Statuta kollegium Lubrańskiego w Poznaniu", Archiwum Teologiczne 1836, 1, No. 2.

BORAS, Z., Tradycje uniwersyteckie Poznania, Poznań 2003.

Dzieje Poznania, vol. 1, parts 1-2: Do roku 1793, ed. J. TOPOLSKI, Warsaw-Poznań 1988.

GOŁĘBIOWSKI, S., "Rola i znaczenie Kolegium Lubrańskiego i Kolegium Jezuickiego w XVI, XVII i XVIII wieku dla Wielkopolski”, Przeglad Wielkopolski 1947, No. 1-3.

GROT, Z., Czterysta lat walki o uniwersytet w Poznaniu, [in:] Dzieje Uniwersytetu im. Adama Mickiewicza 1919-1969, ed. Z. GROT, Poznań 1972.

GROT, Z., Teatr do 1918 r., [in:] Dziesięć wieków Poznania, vol. 2: Kultura umysłowa, literatura, teatr i muzyka, Poznań-Warsaw 1956.

GRZELECKI, W., Szkoty - kolonie Uniwersytetu Krakowskiego 1588-1773. Problematyka ksztatcenia i wychowania, Wrocław 1986.

HAJDUKIEWICZ, L., "Podstawy ideowe i organizacyjne kolonii akademickich Uniwersytetu Krakowskiego (1588-1773/1775). Stan badań, problematyka, postulaty", Przeglad Historyczno-Oświatowy, 1963, 6, No. 2.

KARKUCIŃSKA, W., "Katalog publikacji Drukarni Akademickiej w Poznaniu”, Kronika Miasta Poznania 1999, No. 2: Jan Lubrański i jego dzieło.

KOSSOWSKI, S., "Krzysztof Hegendorfin w akademii Lubrańskiego w Poznaniu w latach 1530 1535. Monografia z dziejów odrodzenia i reformacji w Polsce", Studya do dziejów renesansu i reformacji w Polsce, Lwów 1905.

KOSSOWSKI, S., Christophorus Hegendorphinus in der bischoflinden Akademie zu Posen (1530 1535), Lemberg 1903.

LINETTE, R., "Z dziejów budynku dawnej Akademii Lubrańskiego", Kronika Miasta Poznania 1999, No. 2: Jan Lubrański i jego dzieło.

ŁUKASZEWICZ, J., Historya szkót w Koronie $i$ w Wielkiem Księstwie Litewskiem od najdawniejszych czasów aż do roku 1794, vol. 1-3, Poznań 1849-1851.

ŁUKASZEWICZ, J., Obraz historyczno-statystyczny miasta Poznania $w$ dawniejszych czasach, vol. 1-2, Poznań 1838.

MARCINIAK, R., "Biblioteka biskupa Jana Lubrańskiego", Kronika Miasta Poznania 1999, No. 2: Jan Lubrański i jego dzieło.

MAZURKIEWICZ, K., “Akademia Lubrańskiego w Poznaniu”, Wiadomości dla Duchowieństwa 1926, coll. 7-9.

MAZURKIEWICZ, K., Benedykt Herbest: pedagog-organizator szkoły polskiej XVI wieku, kaznodzieja-misjonarz doby reformacji, Poznań 1925.

MAZURKIEWICZ, K., Początki Akademji Lubrańskiego w Poznaniu (1519-1535). Przyczynek do dziejów rozwoju nauk humanistycznych w Polsce, Poznań 1921.

NOWACKI, J., “Akademia Lubrańskiego”, Kronika Miasta Poznania 1999, no. 2: Jan Lubrański i jego dzieło.

NOWACKI, J., Dzieje archidiecezji poznańskiej, vol. 2, Archidiecezja poznańska $w$ granicach historycznych i jej ustrój, Poznań 1964. 
PAWLACZYK, A., “Krzysztofa Hegendorfa „Racja Studiowania””, Kronika Miasta Poznania 1999, No. 2: Jan Lubrański i jego dzieło.

PAWLACZYK, A., "Statuta Akademii Lubrańskiego z 1619 roku”, Kronika Miasta Poznania 1999, No. 2: Jan Lubrański i jego dzieto.

PIĘTKA, R., "Benedykt Herbest - rektor Akademii Lubrańskiego [w Poznaniu]", Kronika Miasta Poznania 2006, No.4.

PNIEWSKI, W., Akademia poznańska. Szkic historyczny, Poznań 1919.

REZLER, M., "Collegium Lubranscianum”, Gtos Wielkopolski, 1998, 1st ed., no. 231.

SKORUPSKA, Z., Życie umysłowe i literackie do 1793 r., [in:] Dziesięć wieków Poznania, vol. 2: Kultura umystowa, literatura, teatr i muzyka, Poznań-Warsaw 1956.

SKURATOWICZ, J., Akademia Lubrańskiego: pomnik wielkopolskiej kultury i nauki, Poznań 2007.

SKURATOWICZ, J., „Nieznana” Akademia Lubrańskiego w Poznaniu, [in:] Tu się Polska zaczęła...: wydawnictwo pokonferencyjne, ed. H. KÓČKA-KRENZ, Poznań 2007.

SÓJKA, J., "Drukarnia Akademicka w Poznaniu 1689-1780", Kronika Miasta Poznania 1999, No. 2: Jan Lubrański i jego dzieło.

WIESIOŁOWSKI, J., "Krakowscy profesorowie Akademii Lubrańskiego. Materiały", Kronika Miasta Poznania 1999, No. 2: Jan Lubrański i jego dzieło.

WIKTOR, K., “A więc jeszcze przed Soborem Trydenckim”, Przewodnik Katolicki, 1963, 53.

WIKTOR, K., "W cieniu Akademii Lubrańskiego", Przewodnik Katolicki, 1961, 51, No. 41.

WOJTKOWSKI, A., "Czy Akademia Lubrańskiego była uniwersytetem?”, Kronika Miasta Poznania, 1932, No.1.

WOJTKOWSKI, A., “Język grecki w Poznaniu”, Kronika Miasta Poznania 1930, No. 2.

WRZOSEK, A., Założenie Uniwersytetu Poznańskiego i pierwsze lata jego istnienia, Poznań 1924.

ŻOŁĄDŹ-STRZELCZYK, D., “Academia Lubransciana (1519-1780). Dzieje szkoły od powstania do czasów Komisji Edukacji Narodowej”, Kronika Miasta Poznania 1999, No. 2: Jan Lubrański i jego dzieło. 